\title{
National surveillance of occupational exposure to the human immunodeficiency virus
}

Maura RICKetts, MD, MHSc, Linda Deschamps, KImBerly Elmslie, MSC, Michael O’Shaughnessy, PhD

\begin{abstract}
M Ricketts, L Deschamps, K Elmslie, M O'Shaughnessy. National surveillance of occupational exposure to the human immunodeficiency virus in Canada. Can J Infect Dis 1992;3(6):290-294. In September 1985, a prospective study was initiated to monitor the occurrence of occupational exposures to human immunodeficiency virus (HIV)-infected blood and body fluids in Canada. This program was coordinated by the Federal Centre for acquired immune deficiency syndrome (AIDS) (now the Division of HIV/AIDS Epidemiology at the Laboratory Centre for Disease Control). The objective was to determine the risk to workers of acquiring HIV infection as a result of exposure to HIV-infected blood and other body fluids. To be eligible, a worker must have sustained a documented parenteral, mucous membrane or skin contact exposure to blood or body fluids from an HIV-infected person. A baseline specimen was collected within a week of the exposure and then at six weeks, 12 weeks, six months and 12 months. Information concerning the type of exposure, precautions used and post exposure treatment was submitted to the Federal Centre for AIDS on standard data collection forms. All information was anonymous, identified only by a code number. Guidelines for counselling an exposed employee were provided with enrollment material. As of July 29 . 1991, 414 employees have been included in the study. Two hundred and thirty-seven of the 414 exposures $(57 \%)$ were needlestick injuries of which $167(70 \%)$ were sustained by nurses. Other exposures consisted of open wound contamination, eye splashes, scalpel wounds and skin contact with blood and body fluids. To date, there have been no seroconversions among workers enrolled in the surveillance program.
\end{abstract}

Key Words: Human immunodeficiency virus, Occupational exposure, Seroconversions

\section{Étude épidémiologique à l'échelle nationale sur l'exposition professionnelle au virus de l'immunodéficience humaine}

RÉSUMÉ: En 1985, une étude prospective a été amorcée afin de vérifier la fréquence de l'exposition professionnelle à des échantillons de sang et de liquides de l'organisme infectés au virus de l'immunodéficience humaine (VIH) au Canada. Ce programme a été coordonné par le Centre fédéral pour le syndrome de l'immunodéficience acquise (SIDA). L'objectif était de déterminer le risque auquel sont soumis les travailleurs à l'égard de l'infection au VIH acquis, suite à une exposition à du sang et à d'autres liquides de l'organisme infectés au VIH. Pour être admissibles, les travailleurs devaient avoir été soumis à une exposition documentée, soit parentérale, muqueuse ou cutanée, à du sang ou des liquides de l'organisme provenant d'une personne infectée au VIH. Un spécimen de départ était recueilli dans la semaine suivant l'exposition, puis après six semaines, 12 semaines, six mois et 12 mois. Les renseignements au sujet du type d'exposition, les précautions utilisées et le traitement suivant l'exposition ont été soumis au Centre

Laboratory Centre for Disease Control, Health Protection Branch, Health and Welfare Canada, Ottawa, Ontario Correspondence and reprints: Dr Maura Ricketts, Senior Medical Consultant, Division of HIV/AiDs Epidemiology. Laboratory Centre for Disease Control, Tunney's Pasture. Ottawa. Ontario KLA OL2. Telephone (613) 954-8501

Received for publication June 10, 1991. Accepted August 29, 1991 
fédéral pour le SIDA à l'aide des formules standard de cueillette de données. Tous les renseignements étaient anonymes, identifiés seulement par un code numérique. Les directives pour le counselling auprès des employés exposés leur ont été remises avec le matériel d’inscription à l'étude. Au 29 juillet 1991, 414 employés avaient été admis à l'étude. Deux cent trente-sept des 414 cas d'exposition (57\%) concernaient des blessures par piqûre d'aiguille, dont 167 (70 \%) mettaient en cause des infirmières. D'autres types de contaminations sont survenues par plaie ouverte, éclaboussure au niveau des yeux, blessure par scalpel et contact cutané avec du sang et des liquides de l'organisme. Jusqu'à présent, aucune séroconversion ne s'est produite parmi les employés inscrits à ce programme épidémiologique.

$\mathrm{F}$ OR OVER SIX YEARS. STUDIES TO DETERMINE THE RISK TO workers of acquiring human immunodeficiency virus (HIV) infection in the workplace have been ongoing in Canada and the United States.

The occupational health risk of becoming infected with HIV remains low. In the United States, over 1200 health care workers who have sustained an exposure to infected blood and body fluids have been followed by the United States Centers for Disease Control (CDC) (1). The CDC has received reports of seven workers who became infected as a result of needlestick injuries, two from cuts with sharp objects, three from skin contact and one from mucous membrane exposure to blood or blood-containing fluids.

In addition to 13 documented seroconversions in the United States, two workers from France (1), one from the United Kingdom (1), one from Martinique (1) and one from Australia (2) have become infected as the result of needlestick injuries. One other seroconversion occurred via a mucous membrane exposure (1).

Twelve other seroconversions have occurred worldwide, but there is insufficient information to determine whether they represent occupational transmission (1).

\section{SUBJECTS AND METHODS}

In September 1985, a prospective study was initiated to monitor the occurrence of occupational exposures to HIV-infected blood and body fluids in Canada. This program was coordinated by the Federal Centre for acquired immune deficiency syndrome (AIDS). The objective was to determine the risk of acquiring HIV infection as a result of exposure to HIV-infected blood and other body fluids.

Participation was voluntary, with 200 institutions enrolled in the study. A worker must have sustained a documented parenteral, mucous membrane or direct contact to nonintact skin exposure to the blood or body fluids of a patient with AIDS, symptomatic HIV infection or asymptomatic HIV infection to be included in the study. The surveillance protocol required that participants receive HIV serology tests (enzyme-linked immunosorbent assay [ELISA]) within one week of the occupational exposure (baseline specimen). Originally the protocol required blood be taken within 30 days of exposure. In July 1988, the protocol was revised and blood specimens were taken within one week. Sub- sequently, blood was collected post exposure at six weeks, 12 weeks, six months and 12 months (a total of five specimens over the 12-month follow-up).

Confidentiality was assured by the use of a coding system for record management which did not require any personal identification. Serum samples were tested for HIV antibody at the Retrovirus Laboratory of the Federal Centre for AiDs. Employee Health Services or the employee's private physician was responsible for surveillance of the employee, for registering an exposed employee and for collection of blood specimens. Information concerning the employee's medical history, type of exposure, precautions and post exposure treatment was completely anonymous, identified only by a code number, and was submitted to the Federal Centre for AIDS on standard data collection forms.

Guidelines for counselling an exposed employee were provided with the data collection forms and protocol. These guidelines dealt with precautions and lifestyle changes an employee should make during the follow-up period to reduce the potential risk of transmission. Information regarding the use of zidovudine for post exposure chemoprophylaxis was also given.

Statistical methods: Ninety-five per cent confidence intervals for the probability of infection after a single exposure were calculated using the binomial distribution and the methodology of Blyth (7).

\section{RESULTS}

As of July 29, 1991, 414 employees had been included in the study, including 59 individuals who did not have a baseline serum sample taken within 30 days (1985 protocol) and 21 who did not have a baseline serum sample taken within seven days (new protocol). All but one of these individuals were seronegative on their initial test and this person's seropositive status was not attributed to occupational exposure.

The authors have received reports of eight workers who received zidovudine for post exposure chemoprophylaxis: four nurses who sustained moderate needlestick injuries (two when initiating an intravenous, one when drawing blood and the other when recapping a needle after administering an injection); another nurse who received a deep puncture wound when initiating an intravenous; a medical technologist who received a superficial needlestick injury when taking blood from a culture bottle with a needle and syringe; a laboratory 


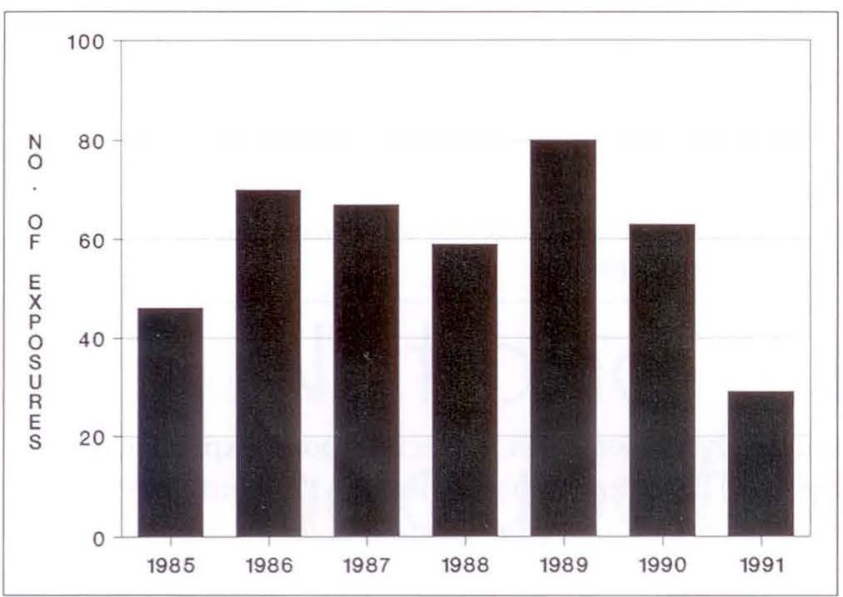

Figure 1) Number of reported exposures per year. $n=414$

technologist who sustained a nonintact skin contact while injecting a blood sample into a culture bottle when the syringe exploded; and a physician who sustained a moderate needlestick injury when drawing arterial blood gases.

Forty-six exposures were reported in 1985, 70 in 1986, 67 in 1987, 59 in 1988, 80 in 1989, 63 in 1990 and 29 as of July 29, 1991 (Figure 1).

Personnel: The type of exposure to HIV by occupational group is presented in Table 1. Three hundred and forty-six parenteral and mucous membrane exposures were reported with $83 \%$ of these occurring among personnel involved in direct patient care: nurses (67\%). therapists and technicians (5\%), medical students and residents $(5 \%)$ and physicians $(6 \%)$. Laboratory technicians sustained $11 \%$ of the reported exposures. The 'other' category (Table 1) comprised three of each of: dentists, police officers, orderlies, ambulance attendants, laundry workers; two dental assistants; as well as one radiographer, phlebotomist, fireman, maintenance worker, messenger, biochemist, nurses' aide, fire security officer and unspecified hospital worker.

Type of exposure: Fifty-seven per cent of the exposures were needlestick injuries (Table 1). In 33 of these cases, the needlestick occurred while recapping a used needle. Thirty-four injuries resulted from improper disposal of used needles. Other exposures were from open wound contaminations (11\%), eye splashes (10\%) and scalpel wounds (5\%). The remaining exposures resulted from skin contact with blood and body fluids (Table 1).

Protective apparel: The types of exposure to HIV according to the protective apparel worn by the workers is described in Table 2. Thirty-eight per cent of workers were not wearing protective apparel at the time of exposure; $44 \%$ of these exposures were needlestick injuries, 33\% were skin contact exposures and 20\% were open wound contaminations. Gloves were worn in $43 \%$ of the needlestick injury accidents. In $70 \%$ of the open wound contaminations, no protective clothing was worn. Gloves, gown and a mask were worn in $44 \%$ of eye splash incidents.

One hundred and sixty-two (39\%) of the exposures may have been prevented by adherence to universal precautions (Table 3). Thirty-three of the 237 needlestick injuries could have been prevented by not recapping needles and 34 incidents could have been prevented by the proper disposal of a used needle. The 44 open wound contaminations could have been prevented by covering open skin areas before beginning procedures. In 51 of the 68 skin contact exposures, no protective apparel was worn. Two hundred and twenty of the 237 needlestick exposures (93\%) and how they occurred are presented in Table 4.

HIV serology test results: There have been no seroconversions among the 334 workers for whom both baseline and follow-up serum samples were obtained.

Statistical analysis: The risk of becoming infected after needlestick exposure to HIV is approximately 4 to $5 \times 10^{-3}$. The risk of infection after mucocutaneous exposure is lower (8). In this study there were no seroconversions in 414 exposures. However, some of these workers were enrolled so recently that they have not had an opportunity to seroconvert. While long periods before seroconversion have been documented, all reported seroconversions in health care workers occurred within six

TABLE 1

Exposures by occupation group

\begin{tabular}{|c|c|c|c|c|c|c|c|}
\hline & Nurse & $\begin{array}{l}\text { Therapist/ } \\
\text { technician }\end{array}$ & $\begin{array}{l}\text { Student/ } \\
\text { resident }\end{array}$ & $\begin{array}{l}\text { Laboratory } \\
\text { technician }\end{array}$ & Physician & Other & Total (\%) \\
\hline Needlestick & 167 & 7 & 16 & 21 & 15 & 11 & $237(57 \%)$ \\
\hline Scalpel wound & 11 & 0 & 2 & 4 & 2 & 3 & $22(5 \%)$ \\
\hline Eye splash & 26 & 6 & 1 & 6 & 3 & 1 & $43(10 \%)$ \\
\hline Open wound & 31 & 2 & 1 & 6 & 1 & 3 & $44(11 \%)$ \\
\hline \multicolumn{8}{|l|}{ Skin contact: } \\
\hline intact & 2 & 1 & 0 & 1 & 1 & 4 & $9(2 \%)$ \\
\hline nonintact & 10 & 1 & 0 & 5 & 1 & 1 & $18(5 \%)$ \\
\hline unknown & 33 & 3 & 0 & 2 & 0 & 3 & $41(10 \%)$ \\
\hline Total (\%) & $280(67 \%)$ & $20(5 \%)$ & $20(5 \%)$ & $43(11 \%)$ & $23(6 \%)$ & $26(6 \%)$ & $414(100 \%)$ \\
\hline
\end{tabular}




\begin{tabular}{|c|c|c|c|c|c|c|c|c|}
\hline & $\begin{array}{l}\text { Gloves } \\
\text { only }\end{array}$ & $\begin{array}{l}\text { Gown and } \\
\text { gloves }\end{array}$ & $\begin{array}{l}\text { Gloves } \\
\text { and mask }\end{array}$ & $\begin{array}{l}\text { Gloves, gown } \\
\text { and mask }\end{array}$ & $\begin{array}{l}\text { Gloves, } \\
\text { gown, mask } \\
\text { and eye } \\
\text { protection }\end{array}$ & $\begin{array}{l}\text { Mask } \\
\text { and/or } \\
\text { gown }\end{array}$ & $\begin{array}{c}\text { No } \\
\text { protection }\end{array}$ & Total (\%) \\
\hline Needlestick & 102 & 27 & 5 & 15 & 14 & 5 & 69 & $237(57 \%)$ \\
\hline Scalpel wound & 10 & 2 & 1 & 3 & 2 & 1 & 3 & $22(5 \%)$ \\
\hline Eye splash & 11 & 6 & 3 & 19 & 2 & 0 & 2 & $43(10 \%)$ \\
\hline $\begin{array}{l}\text { Open wound } \\
\text { contamination }\end{array}$ & 5 & 2 & 1 & 2 & 2 & 1 & 31 & $44(11 \%)$ \\
\hline \multicolumn{9}{|l|}{ Skin contact: } \\
\hline intact & 0 & 0 & 1 & 1 & 0 & 0 & 7 & $9(2 \%)$ \\
\hline nonintact & 4 & 1 & 0 & 0 & 0 & 2 & 11 & $18(5 \%)$ \\
\hline unknown & 3 & 0 & 2 & 1 & 0 & 2 & 33 & $41(10 \%)$ \\
\hline Total $(\%)$ & $135(33 \%)$ & $38(9 \%)$ & $13(3 \%)$ & $41(10 \%)$ & $20(5 \%)$ & $11(3 \%)$ & $156(38 \%)$ & $414(100 \%)$ \\
\hline
\end{tabular}

TABLE 3

Preventable exposures to blood/body fluids

\begin{tabular}{lc}
\hline Description of exposure & $\begin{array}{c}\text { Number of health care } \\
\text { workers (\%) }\end{array}$ \\
\hline Recapping a used needle & $33(20 \%)$ \\
Improper needle disposal & $34(21 \%)$ \\
Open wound contamination & $44(27 \%)$ \\
Skin contact & $51(31 \%)$ \\
Total & $162(100 \%)$ \\
\hline
\end{tabular}

months, most within three months. In the United States, the CDC recommends that workers be tested as soon as possible after exposure and retested periodically for a minimum of six months after exposure (eg, at six weeks, 12 weeks and six months) (9). In Canada, 390 occupationally exposed health care workers were observed for six months or longer. Using the method of Blyth for the calculation of confidence intervals for a binomial distribution, the probability of infection based upon zero seroconversions in 390 exposures was 0 to $7.7 \times 10^{-3}$ at the $95 \%$ confidence level.

\section{DISCUSSION}

The results from this study support a low risk of occupationally acquired HIV infection among workers in Canada. However, given the known risk of one seroconversion per 250 needlestick exposures, it is likely a reported exposure will result in seroconversion. Descriptive statistics from this study have value in outlining some of the associations between high risk exposures and certain characteristics of the accidents.

Insufficient reporting and volunteer bias influence the enrollment of the National Surveillance of Occupational Exposure Program. At least one large Canadian hospital with a relatively high prevalence of HIV-infected patients reports independently (no seroconversions have been reported from this hospital [6]).

The impact of enrollment biases is difficult to predict, but the greatest concern is that bias may lead
TABLE 4

Description of exposures for 220 workers exposed to HIV when using a needle

\begin{tabular}{lc}
\hline Description of exposure & Number of workers \\
\hline Drawing blood & 58 \\
Intravenous administration & 57 \\
Giving an injection & 38 \\
Recapping a used needle & 33 \\
Improper disposal & 34 \\
\hline
\end{tabular}

to underestimation of actual risk. It is possible that there is systematic bias in the type of exposures reported to a federal surveillance system. For example, very high risk exposures such as deep needlesticks, which are most likely to lead to seroconversion, may not systematically be reported to the federal surveillance system because of fear of identification. This seems unlikely since this surveillance system is anonymous the blood work can be analyzed by the National Retrovirus Laboratory and any decisions regarding provincial reporting requirements will be made by the health care workers and their hospital reporting official. Another possible bias is the systematic misclassification of 'no' risk exposures, such as small volume intact skin exposures or as 'low' risk exposures, ie, broken skin exposures. If this misclassification occurs, it would take larger enrollment before a seroconversion would occur. However, infection control and occupational health officers have gained experience in assessing the quality of exposures over the past five years and there is considerable reluctance to misclassify a health care worker as either 'exposed' or 'unexposed'. The recent revision of this study's case report form incorporates a classification system for exposures into high, medium and low risk.

The importance of universal precautions in the prevention of accidental occupational exposure to contaminated body fluids has been discussed by many authors. In this study, the person completing the report 
form (infection control officer or occupational health officer) stated that many of the reported exposures could have been prevented by adherence to universal precaution guidelines. Birnbaum et al $(3,4)$ have investigated compliance with 'universal precautions' and 'body substance isolation' in Canadian hospitals. These workers found $74 \%$ of responders to a questionnaire claimed to have adopted universal precaution guidelines or body substance isolation. However, they found that only $5 \%$ of those claiming adoption of Laboratory Centre for Disease Control universal precaution guideline recommendations actually have adopted all of the fundamental policies. Birnbaum et al comment upon the effectiveness of teaching strategies designed to educate staff about new measures to avoid occupational exposures and comment upon the need for research to investigate appropriate strategies to cause effective behaviour change. Education programs and the means to adhere to recommended procedures should be made available for workers who, during the course of their duties, may come in contact with blood or body fluids. Innovative methodologies for 'safe' needle handling, as reported by Canadian authors $\mathrm{Ng}$ et al (5), are essential to the implementation of universal precaution guidelines. Health care workers should be familiar with infection control guidelines to avoid accidental exposure to HIV and other blood-borne pathogens such as hepatitis $\mathrm{B}$ and $\mathrm{C}$ viruses. In the new case report forms, the authors will endeavour to collect information regarding universal precautions.

The surveillance program is being expanded to include workers such as emergency responders, correctional facility workers and funeral care workers. More information will be collected on the types of precautions taken by employees when performing procedures. In-

\section{REFERENCES}

1. Marcus R, Kay K, Mann JM. Transmission of human immunodeficiency virus (HIV) in health-care settings worldwide. WHO Bulletin 1989:67:577-82.

2. Looke DFM, Grove DI. Failed prophylactic zidovudine after needlestick injury. Lancet, 1990;i:1280. (Lett)

3. Birnbaum D, Schulzer M, Mathias RG, Kelly M, Chow AW. Adoption of guidelines for universal precautions and body substance isolation in Canadian acute-care hospitals. Infection Control Hosp Epidemiol 1990: 11:465-72.

4. Birnbaum D, Schulzer M, Mathias RG, Kelly M, Chow AW. Needlestick injury: Do preventive measures work? Dimensions Health Service (Canadian Hospital Association), 1990:29-32. formation will also be collected on the use of post exposure chemoprophylaxis such as zidovudine.

\section{ADDENDUM: OCCUPATIONAL TRANSMISSION OF HIV - THE FIRST REPORTED CASE IN CANADA}

In 1990, the Ottawa-Carleton Health Department received a report of HIV infection with symptoms of AIDS in an elderly woman. She had been tested three times by ELISA (each test had been confirmed by Western Blot). Early in 1990 the woman developed HIV encephalopathy and esophageal candidiasis. She also had episodes of diarrhea with weight loss (which had begin in December 1988). By February 1990, other reported symptoms included dysphagia, hearing loss, loss of balance and weakness in her arms. She died in August 1990

The woman had been a biochemist who worked in several laboratories during her long career before retiring in 1985; during her work she had experienced at least one incident in which she may have come into contact with HIV-contaminated blood. The woman had been a widow for over 30 years and reported no sexual contact since her husband's death. She had no history of blood transfusions and her only surgery was a lens replacement for cataracts.

This case is the first reported incident of HIV infection presumed to result from an occupational exposure in Canada (28). The patient was not enrolled in the National Surveillance of Occupational Exposure to HIV because the program was initiated after she retired.

For information on the surveillance program or to request enrollment materials please contact: Division of HIV/AIDS Epidemiology. Laboratory Centre for Disease Control. Tunney's Pasture, Ottawa. Ontario KLA OL2, telephone (613) 957-1813.

5. Ng T, Volkening RT. Evans S. A 'point' of view - One hospital's experience in the safe handling and disposal of sharps. Can J Infect Control 1991:6:35-7.

6. Strickler AC. Occupational Exposure to HIV infection among health-care workers at the Toronto General Hospital. CDWR 1988:14:141-6.

7. Blyth CR. Approximate binomial confidence limits. J Am Stat Assoc 1986:81:843-55.

8. Lowenfels AB, Wormser GP, Jain R. Frequency of puncture injuries in surgeons and estimated risk of HIV infection. Arch Surg 1989;124:1284-6.

9. Centers for Disease Control. Public health service statement on management of occupational exposure to human immunodeficiency virus, including considerations regarding zidovudine postexposure use. MMWR 1990:39:1-14. 


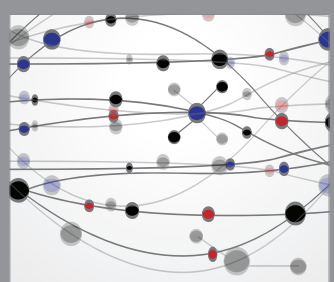

The Scientific World Journal
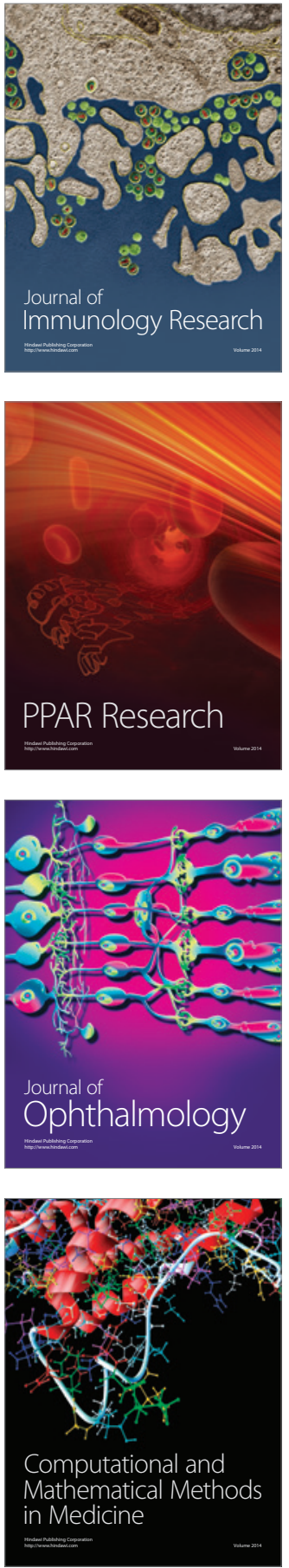

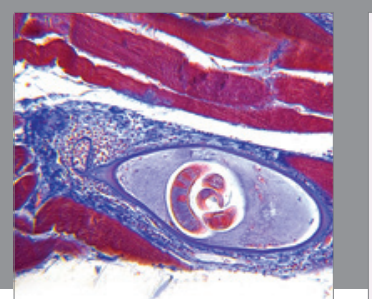

Gastroenterology Research and Practice

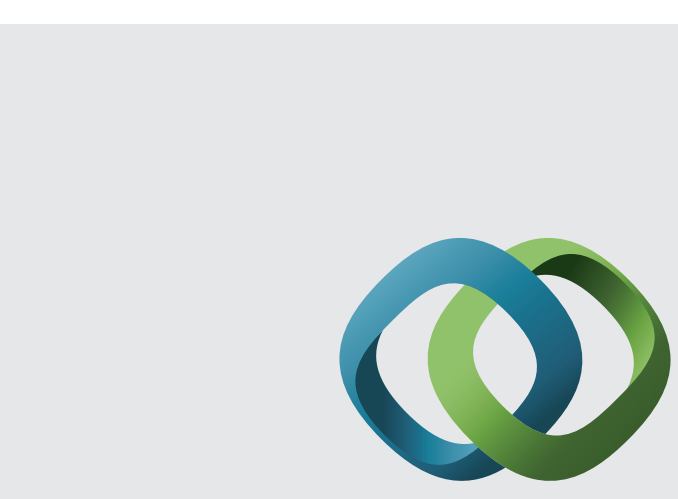

\section{Hindawi}

Submit your manuscripts at

http://www.hindawi.com
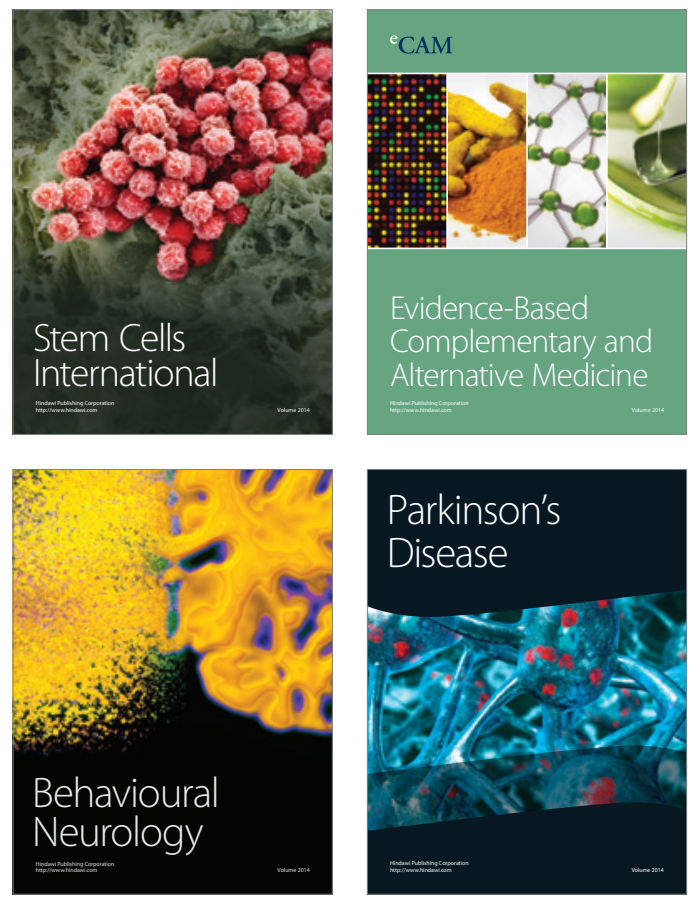
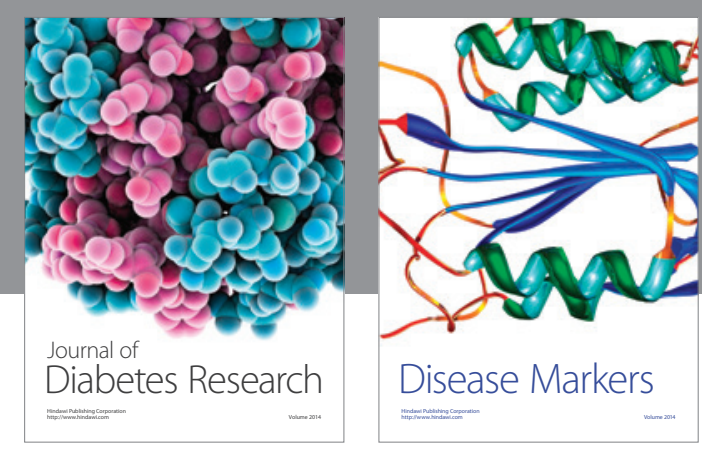

Disease Markers
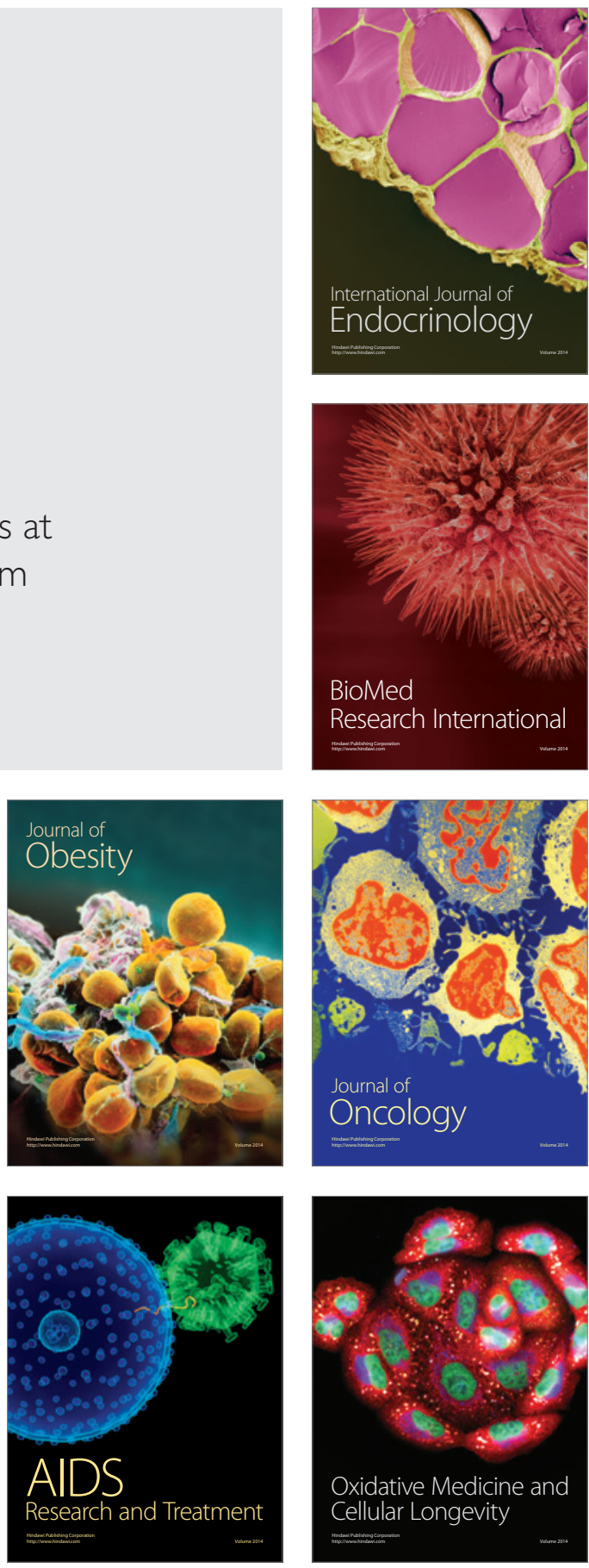